\title{
Identification of New Races and Deviating Strains of the Spinach Downy Mildew Pathogen Peronospora farinosa f. sp. spinaciae
}

\author{
Chunda Feng and James C. Correll, Department of Plant Pathology, University of Arkansas, Fayetteville, AR 72701; and Katherine \\ E. Kammeijer and Steven T. Koike, University of California Cooperative Extension, Salinas, CA 93901
}

\begin{abstract}
Feng, C., Correll, J. C., Kammeijer, K. E., and Koike, S. T. 2014. Identification of new races and deviating strains of the spinach downy mildew pathogen Peronospora farinosa f. sp. spinaciae. Plant Dis. 98:145-152.

Spinach downy mildew disease, caused by the obligate pathogen Peronospora farinosa f. sp. spinaciae, is the most economically important spinach (Spinacia oleracea) disease. New races of this pathogen have been emerging at a rapid rate over the last 15 years. This is likely due to production changes, particularly in California, such as high-density plantings and year-round spinach production. As of 2004, 10 races of $P$. farinosa f. sp. spinaciae had been identified, and the spinach resistance locus $R P F 2$ provided resistance to races 1 to 10 . Based on disease reactions on a set of spinach differentials containing six hypothesized resistance loci (RPF1-RPF6), races 11, 12, 13, and 14 of $P$. farinosa f. sp. spinaciae were characterized based on samples collected in the past 5 years as part of this study. Race 11, identified in 2008 , could overcome the resistance of spinach cultivars resistant to races 1 to 10 . Spinach resistance loci $R P F 1, R P F 3$, and $R P F 6$ provided resistance to race 11. Race 12 was identified in 2009 and could over-

come the resistances of the RPF1 and RPF2 loci. The RPF3 locus was effective against race 12 . Race 13 was identified in 2010 and could overcome the resistance imparted by the $R P F 2$ and $R P F 3$ loci, whereas the $R P F 1$ locus was effective against race 13 . Race 14 was similar to race 12 and caused identical disease responses on the standard differentials but could be distinguished from race 12 by its ability to cause disease on a number of newly released cultivars, including 'Pigeon', 'Cello', and 'Celesta'. Five novel strains of $P$. farinosa f. sp. spinaciae were also identified. For example, isolate UA4711 of the pathogen, collected from Spain in 2011, was able to overcome the resistance imparted by the RPF1 and RPF3 loci, while $R P F 2$ and $R P F 4$ were effective against this strain. A total of 116 spinach cultivars, including 103 commercial lines and 13 differential cultivars, were evaluated for resistance to race 10 and the newly designated races $11,12,13$, and 14 .
\end{abstract}

Spinach (Spinacia oleracea L.) is a nutritious and an increasingly popular vegetable $(9,14,15)$. Interest in a healthier diet has created a dramatic increase in per capita consumption of spinach in the United States from $0.23 \mathrm{~kg}$ in 1990 to $1.00 \mathrm{~kg}$ in 2005 (NASS, http://www.nass.usda.gov). The availability of spinach as a convenient precleaned and packaged commodity has also promoted the consumption of spinach. Fresh market spinach was formerly planted in two to six seed lines on 1-m-wide planting beds and was marketed as bunched fresh, canned, or frozen commodities. In the past two decades, fresh market spinach production and consumption has been increased considerably with the marketing of clipped, bagged "baby leaf" spinach. In California, where over $80 \%$ of the fresh market spinach is produced (NASS, 2011, http://www.nass. usda.gov), the crop is now planted in up to 48 seed lines on 2-mwide beds and harvested 21 to 55 days after planting. This highdensity spinach production provides conditions more conducive for disease development. Also, year-round spinach planting can provide a green bridge for carryover of pathogen inoculum, particularly for diseases caused by obligate plant pathogens such as the downy mildew pathogen. There has also been an increase in organic production of baby leaf spinach. These factors, combined with the release of many new hybrid spinach cultivars with new combinations of resistance loci for downy mildew, likely have increased selection pressure on the downy mildew pathogen and thus have contributed to the increase in disease.

Downy mildew, caused by the obligate pathogen Peronospora farinosa $\mathrm{f}$. sp. spinaciae Byford $(=P$. effusa), is the most economically important spinach disease $(4,5,8)$. This pathogen is host spe-

Corresponding author: James C. Correll, E-mail: jcorrell@uark.edu

Accepted for publication 20 August 2013.

http://dx.doi.org/10.1094/PDIS-04-13-0435-RE

(C) 2014 The American Phytopathological Society cific to spinach and does not infect other plants. The first report of this pathogen infecting spinach was published in 1824 , followed by race 2 in 1958 and race 3 in 1976 (2). Race 4 of $P$. farinosa f. sp. spinaciae was identified in 1990 in California and Texas $(1,3,7)$. Subsequent races were identified in rapid succession: race 5 in 1996 (Colorado) and in 1998 (Europe), race 6 in 1998, race 7 in 1999, and races 8, 9, and 10 in 2004 (12,13). Race 10 was highly pathogenic, and in 2004 only a few cultivars, such as 'Lazio', 'El Dorado', 'El Palmar', 'Emilia', and 'Lombardia', had resistance to this race in 2004 (12). However, in the past few years, downy mildew disease was found on cultivars resistant to races 1 to 10 , indicating additional new races of $P$. farinosa $\mathrm{f}$. sp. spinaciae likely were emerging. Currently, the only means to identify races of the pathogen is by conducting a disease reaction assay on a set of diverse spinach differentials which contains different resistance genes to the downy mildew pathogen. The objectives of this study were to characterize several novel strains of the downy mildew pathogen based on disease reactions on a standardized set of spinach differentials and to evaluate disease reactions of a number of contemporary spinach cultivars to various races and novel strains.

\section{Materials and Methods}

International sanctioning of downy mildew isolates. The International Working Group on Peronospora (IWGP) is headquartered in the Netherlands and meets annually to discuss the development of novel strains of $P$. farinosa f. sp. spinaciae from samples collected around the world. Typically, the data about a novel strain are evaluated by the group and, based on the distribution and the frequency by which a novel strain occurs, a "ringtest" is conducted whereby the participating laboratories conduct parallel tests on the isolate supplied by a single laboratory. If indeed the results of such tests are consistent among the laboratories, and the strain appears to have a distinct virulence phenotype, the novel strain is sanctioned as a new race and assigned a race number. The purpose of such an approach is to authenticate important deviating strains and avoid giving a race designation to transitory deviating strains that 
may not persist or may only be capable of infecting a limited set of spinach lines. Isolates used in this study (races 11, 12, 13, and 14) have been authenticated and sanctioned by the IWGP.

Isolates of $\boldsymbol{P}$. farinosa $\mathbf{f}$. sp. spinaciae evaluated. Opportunistic sampling was done to recover field isolates from spinach cultivars that had previously been reported or observed to be resistant to the downy mildew pathogen. Isolates of $P$. farinosa f. sp. spinaciae were collected from symptomatic leaves from commercial spinach fields or experimental field trials and either directly used to inocu- late the universally susceptible cultivar 'Viroflay' or frozen for processing at a later date. A total of 188 isolates were recovered from California, Arizona, or Texas, and single isolates were recovered from New Jersey, Spain, and the Netherlands. Of these isolates, a total of 60 were characterized for their race identification based on multiple inoculation tests (more than three) on a standardized set of spinach differentials (Table 1). The race of the other 128 isolates was determined by inoculating them once onto the differentials as part of the race survey (Fig. 1).

Table 1. Isolates of Peronospora farinosa f. sp. spinaciae, their cultivar and geographical origins, and race determination

\begin{tabular}{|c|c|c|c|c|}
\hline Isolate & Host cultivar/line ${ }^{\mathrm{a}}$ & Origin & Date received & Race identification $^{b}$ \\
\hline PM2 & Lazio & CA & $11 / 16 / 2007$ & Novel strain \\
\hline UA0508A & Emilia & $\mathrm{CA}$ & $1 / 30 / 2008$ & 3 \\
\hline UA0508B & 157 & $\mathrm{TX}$ & $1 / 30 / 2008$ & 4 \\
\hline UA2708 & Pelican ${ }^{\mathrm{a}}$ & $\mathrm{CA}$ & $7 / 2 / 2008$ & Mixed isolate \\
\hline UA2708PL ${ }^{c}$ & & & & 11 \\
\hline UA0209B & Misano & $\mathrm{AZ}$ & $1 / 8 / 2009$ & 11 \\
\hline UA0209D & Ottawa & $\mathrm{AZ}$ & $1 / 9 / 2009$ & Novel strain \\
\hline UA0309 & Thames & $\mathrm{CA}$ & $1 / 15 / 2009$ & 11 \\
\hline UA1509A & Cannon & CA & $4 / 7 / 2009$ & 11 \\
\hline UA2209 & Mississippi $^{\mathrm{a}}$ & $\mathrm{CA}$ & $5 / 30 / 2009$ & 12 \\
\hline UA2509A & Whale & $\mathrm{CA}$ & $6 / 16 / 2009$ & 10 \\
\hline UA2509B & Tbird & $\mathrm{CA}$ & $6 / 16 / 2009$ & 11 \\
\hline UA3209 & Vigore & $\mathrm{CA}$ & $8 / 4 / 2009$ & 12 \\
\hline UA3309A & PV7154 & $\mathrm{CA}$ & $8 / 12 / 2009$ & 12 \\
\hline UA3409 & Missouri & $\mathrm{CA}$ & $8 / 18 / 2009$ & 12 \\
\hline UA4309 & Unknown & WA & $10 / 20 / 2009$ & 12 \\
\hline UA4609A & E80.8373 & $\mathrm{CA}$ & $11 / 10 / 2009$ & 10 \\
\hline UA0510A & Flamingo & $\mathrm{AZ}$ & $1 / 24 / 2010$ & 13 \\
\hline UA0510C & Charger ${ }^{\mathrm{a}}$ & $\mathrm{AZ}$ & $1 / 27 / 2010$ & 13 \\
\hline UA0710 & El Patriot & $\mathrm{CA}$ & $2 / 11 / 2010$ & 13 \\
\hline UA1210A & Zebu & $\mathrm{AZ}$ & $3 / 18 / 2010$ & Novel strain \\
\hline UA1410 & El Patriot & $\mathrm{AZ}$ & $4 / 1 / 2010$ & 11 \\
\hline UA1510 & Verde & $\mathrm{AZ}$ & 4/9/2010 & 4 \\
\hline UA2110 & Tennessee & $\mathrm{CA}$ & $5 / 20 / 2010$ & 12 \\
\hline UA2510 & E80.8397 & $\mathrm{CA}$ & $6 / 16 / 2010$ & 12 \\
\hline UA3610 & Flamingo & CA & $9 / 2 / 2010$ & 13 \\
\hline UA4410 & Pigeon $^{\mathrm{a}}$ & $\mathrm{CA}$ & $10 / 27 / 2010$ & 14 \\
\hline UA0811 & Tasman & $\mathrm{CA}$ & $2 / 15 / 2011$ & 13 \\
\hline UA1411A & Raccoon & $\mathrm{CA}$ & $3 / 31 / 2011$ & 13 \\
\hline UA1411B & Amazon & $\mathrm{CA}$ & $3 / 31 / 2011$ & 12 \\
\hline UA1811 & Raccoon & $\mathrm{CA}$ & 4/29/2011 & 13 \\
\hline UA2011 & Whale & $\mathrm{CA}$ & $5 / 10 / 2011$ & 13 \\
\hline UA2111 & Andromeda & CA & $5 / 17 / 2011$ & 13 \\
\hline UA2311A & Golden Whale & $\mathrm{CA}$ & $6 / 2 / 2011$ & 13 \\
\hline UA2411 & Violin & $\mathrm{CA}$ & $6 / 7 / 2011$ & 13 \\
\hline UA2511A & Pigeon & $\mathrm{CA}$ & $6 / 15 / 2011$ & $12+13$ \\
\hline UA2611A & Mississippi & $\mathrm{CA}$ & $6 / 20 / 2011$ & Mixed isolate \\
\hline UA2711 & FY10599 & CA & $6 / 28 / 2011$ & Mixed isolate \\
\hline UA3011 & Pigeon & $\mathrm{CA}$ & $7 / 20 / 2011$ & Mixed isolate \\
\hline UA3111 & Celesta & CA & $7 / 29 / 2011$ & 14 \\
\hline UA3411A & Multi-cultivars & $\mathrm{CA}$ & $8 / 16 / 2011$ & 13 \\
\hline UA3611 & PV0293 & $\mathrm{CA}$ & $8 / 24 / 2011$ & 14 \\
\hline UA4211 & Cello & $\mathrm{CA}$ & $10 / 6 / 2011$ & 14 \\
\hline UA4311 & Silver Whale & $\mathrm{CA}$ & $10 / 13 / 2011$ & 10 \\
\hline UA4711 & Unknown & Spain & $11 / 16 / 2011$ & Novel strain \\
\hline UA0312A & Tasman & CA & $1 / 18 / 2012$ & 13 \\
\hline UA0312B & Tonga & CA & $1 / 19 / 2012$ & 12 \\
\hline UA1312 & Unknown & Netherlands & $3 / 28 / 2012$ & Novel strain \\
\hline UA1412 & Pigeon & $\mathrm{AZ}$ & $4 / 5 / 2012$ & 14 \\
\hline UA $1512 \mathrm{~A}$ & Cello & $\mathrm{AZ}$ & $4 / 10 / 2012$ & 13 \\
\hline UA1512B & Tambourine & $\mathrm{AZ}$ & $4 / 10 / 2012$ & 12 or 14 \\
\hline UA1612A & PV1388 & $\mathrm{CA}$ & $4 / 17 / 2012$ & 4 \\
\hline UA1612B & Chevelle & $\mathrm{AZ}$ & $4 / 17 / 2012$ & 4 \\
\hline UA1812A & Cello & CA & $5 / 3 / 2012$ & 14 \\
\hline UA1812B & Amazon & $\mathrm{CA}$ & $5 / 3 / 2012$ & 14 \\
\hline UA2012 & Solomen & $\mathrm{CA}$ & $5 / 15 / 2012$ & 10 \\
\hline UA2112 & Unipack 12 & $\mathrm{NJ}$ & $5 / 24 / 2012$ & 3 \\
\hline UA2312 & Unknown & $\mathrm{CA}$ & $6 / 7 / 6012$ & 13 \\
\hline UA2412 & Chevelle & $\mathrm{CA}$ & $6 / 14 / 2012$ & 13 \\
\hline UA2612 & Pigeon & $\mathrm{CA}$ & $6 / 29 / 2012$ & Novel strain \\
\hline
\end{tabular}

a The cultivar or line from which the original isolate of the new race was collected.

$\mathrm{b}$ The race identification was determined by the disease reactions of differential cultivars.

c UA2708PL is derived from isolate UA2708. 
Spinach cultivars, hybrids, and advanced breeding lines used for characterization of $\boldsymbol{P}$. farinosa $\mathbf{f}$. sp. spinaciae. A set of 10 differential cultivars established at the University of Arkansas (UA) (12) was used to identify races of $P$. farinosa f. sp. spinaciae (Table 2). A slightly different set of differentials (Table 2) is typically used in the European Union (EU). Both the UA and the EU differential sets, along with a total of 103 spinach hybrids, cultivars, and advanced breeding lines, were used to characterize the previously described race 10 and the four novel races of $P$. farinosa f. sp. spinaciae identified in the current study (Table 3). Seed of the spinach differentials and select isolates of $P$. farinosa f. sp. spinaciae are available from the authors or from http://www.worldseed.org/isf/ strain_identification.html\#1.

Based on the known resistances, near isogenic lines (NILs) are being developed using the susceptible cultivar Viroflay as the recurrent parent. Each NIL contains only one downy mildew resistance locus, selected with corresponding races of the pathogen $(4,6,11)$. NIL1 and NIL2, containing the resistant loci RPF1 and $R P F 2$, respectively, have been developed at the UA, and have been tested against all of the known races.

Pesticide-free spinach seed was sown in $25 \times 50 \mathrm{~cm}^{2}$ plastic trays filled with Sunshine LC1 potting soil (Sun Gro Horticulture,
Agawarn, MA) in 10 rows per flat and 20 seeds per row. Plants were watered daily and fertilized weekly with Miracle Gro All Purpose Plant Food (20-20-20, 10 g/4 liters). Plants were grown in a greenhouse at 15 to $25^{\circ} \mathrm{C}$ (night time low/day time high). Twoweek-old plants were used for inoculation.

Inoculation and disease rating. Inoculations and disease ratings were performed as previously described (11). Briefly, sporangia used for inoculum were collect from either freshly collected leaves or leaves stored at $-80^{\circ} \mathrm{C}$. Infected spinach leaves were washed by shaking and swirling them in chilled $\left(4^{\circ} \mathrm{C}\right)$ water. The sporangia were then filtered through two layers of cheesecloth, and the inoculum concentration was adjusted to $10^{5} \mathrm{sporangia} / \mathrm{ml}$. Each flat of plants was sprayed with $20 \mathrm{ml}$ of inoculum using a Badger Basic Spray Gun (Model 250). Inoculated plants were incubated in a dew chamber at $100 \%$ relative humidity and $18^{\circ} \mathrm{C}$ for $24 \mathrm{~h}$. The plants were then moved to a growth chamber maintained at 18 to $20^{\circ} \mathrm{C}$ with a $12 \mathrm{~h}$ light $/ 12 \mathrm{~h}$ dark regime. Six days after inoculation, plants were moved back to the dew chamber for $24 \mathrm{~h}$ to induce sporulation, and then scored for the disease reaction.

Disease evaluations were performed on each seedling based on the presence of symptoms of downy mildew disease as previously

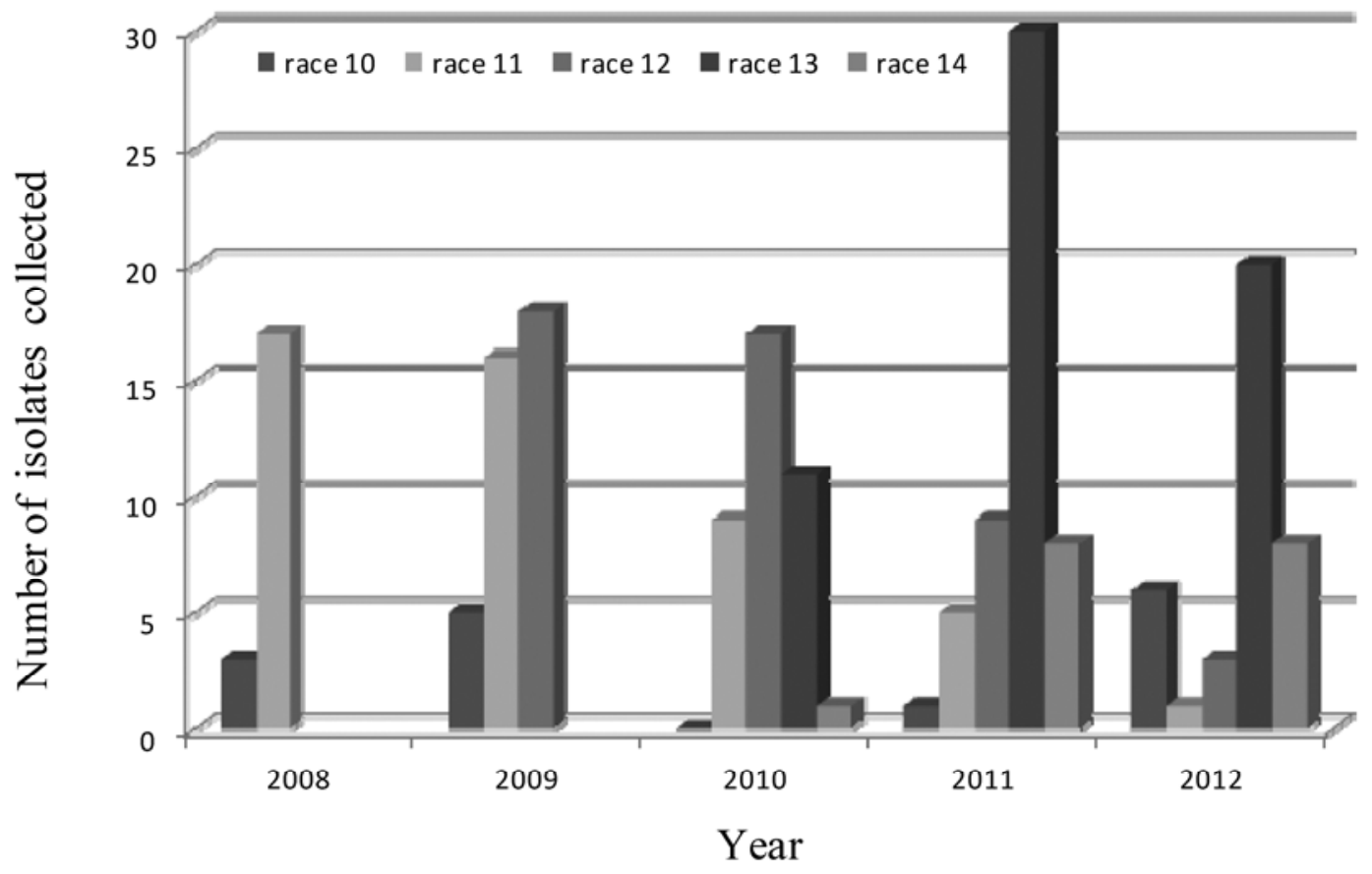

Fig. 1. Frequency of spinach downy mildew races based on 188 survey samples of isolates of Peronospora farinosa f. sp. spinaciae collected during 2008 to 2012.

Table 2. Disease responses of the two sets of spinach differential cultivars used in the EU and at the UA to different races of the downy mildew pathogen ${ }^{\mathrm{a}}$

\begin{tabular}{|c|c|c|c|c|c|c|c|c|c|c|c|c|c|c|c|c|c|}
\hline \multirow[b]{2}{*}{ Differential } & \multicolumn{2}{|c|}{ Parental resistance } & \multicolumn{14}{|c|}{ Race } & \multirow{2}{*}{$\frac{\text { Institute }}{\text { UA\&EU }}$} \\
\hline & Male & Female & 1 & 2 & 3 & 4 & 5 & 6 & 7 & 8 & 9 & 10 & 11 & 12 & 13 & 14 & \\
\hline Viroflay & & & + & + & + & + & + & + & + & + & + & + & + & + & + & + & UA\&EU \\
\hline Resistoflay & RPF5 & & - & - & + & + & + & + & + & + & + & + & + & + & + & + & UA\&EU \\
\hline Califlay & & RPF3 & - & + & - & + & - & + & + & - & - & + & - & - & + & - & UA\&EU \\
\hline Polka & RPF3 & RPF5 & - & - & - & + & _- & + & + & _- & _- & + & - & - & + & - & UA\&EU \\
\hline Bolero & RPF4 & RPF5 & - & - & - & - & + & + & + & + & + & + & + & + & + & + & UA \\
\hline Campania & RPF6 & RPF4 & - & - & - & - & - & + & - & + & + & + & - & + & + & + & UA\&EU \\
\hline Dolphin & RPF1 & CMV & - & - & _- & - & - & - & - & + & - & + & _- & + & - & + & UA \\
\hline Avenger & RPF1 & RPF5 & - & - & - & - & - & - & - & + & - & + & - & + & - & + & UA \\
\hline Lion & RPF1 & RPF3 & - & - & - & - & - & _- & - & - & - & + & - & - & - & - & UA\&EU \\
\hline Lazio & RPF2 & RPF4 & - & - & - & - & - & - & - & - & - & - & + & + & + & + & UA\&EU \\
\hline Clermont & RPF4 & RPF5 & - & - & - & - & + & + & + & + & + & + & + & + & + & + & EU \\
\hline Boeing & RFP1 & RPF5 & - & - & - & - & - & - & - & + & - & + & - & + & - & + & EU \\
\hline Whale & & RPF3 & _- & - & _- & + & - & + & + & _ & - & + & _- & - & + & - & EU \\
\hline
\end{tabular}

${ }^{a}$ A plant showing chlorosis and sporulation on cotyledons, true leaves, or both was classified as susceptible (+), while a plant without chlorosis or sporulation was rated as resistant (-). A spinach line was classified as susceptible if more than $85 \%$ of the plants were diseased (+), whereas a line was classified as resistant if less than $15 \%$ of plants were diseased (-). EU: the European Union; UA: the University of Arkansas. 
described (12). A plant showing chlorosis and evidence of sporulation on cotyledons, true leaves, or both was classified as susceptible $(+)$, whereas plants lacking chlorosis or sporulation were rated as resistant (-). Following previous criteria for evaluating resistance (12), a spinach line was classified as susceptible if more than $85 \%$ of the plants were susceptible, whereas a line was classi- fied as resistant if more than $85 \%$ of plants were resistant. More than $15 \%$ but less than $85 \%$ of susceptible plants could indicate that a line was segregating for resistance (i.e., +/-), the line was a mixture of different spinach genotypes, there was an unusually high number of inbred plants in the line, or multiple races were present in a given sample.

Table 3. Resistance screening of 116 spinach cultivars to the newly described races of the downy mildew pathogen ${ }^{\mathrm{a}}$

\begin{tabular}{|c|c|c|c|c|c|}
\hline Cultivar/line & Race 10 (INT-1) & Race 11 (UA2708PL) & Race 12 (UA2209) & Race 13 (UA0510C) & Race 14 (UA4410) \\
\hline Viroflay & + & + & + & + & + \\
\hline Resistoflay & + & + & + & + & + \\
\hline Califlay & + & - & - & + & _- \\
\hline Bolero & + & + & + & + & + \\
\hline Campania & + & - & + & + & + \\
\hline Avenger & + & - & + & - & + \\
\hline Lion & + & - & - & - & - \\
\hline Lazio & - & + & + & + & + \\
\hline Dolphin & + & - & + & - & + \\
\hline Polka & + & - & - & + & - \\
\hline Clermont & + & + & + & + & + \\
\hline Boeing & + & - & + & - & + \\
\hline Whale & + & - & - & + & - \\
\hline 501 & - & + & + & + & + \\
\hline 505 & - & + & + & + & + \\
\hline 692 & - & - & - & - & - \\
\hline 80.8373 & + & _- & _- & - & + \\
\hline 80.8393 & + & - & - & - & + \\
\hline 80.9448 & - & - & - & - & + \\
\hline 8031 & + & - & - & + & - \\
\hline 8032 & - & - & - & + & - \\
\hline 8078 & + & _- & - & + & _- \\
\hline 8079 & - & - & - & + & - \\
\hline 8184 & + & - & - & + & - \\
\hline 8185 & - & - & - & + & - \\
\hline 51-315 (Cello) & - & - & $+1-$ & - & + \\
\hline $51-703$ & - & - & + & - & + \\
\hline 51-704 (Celesta) & - & - & - & - & + \\
\hline $80-5224$ & - & - & + & - & + \\
\hline $80-6280$ & - & - & + & - & + \\
\hline $03-316$ & + & + & + & + & + \\
\hline $04-103$ & + & + & + & + & + \\
\hline $88-130$ & + & + & + & + & + \\
\hline $88-212$ & + & + & + & + & + \\
\hline $88-310$ & + & + & + & + & + \\
\hline $91-227$ & + & + & + & + & + \\
\hline $97-154$ & + & + & + & + & + \\
\hline Amazon & - & - & + & - & + \\
\hline Bahamas & - & - & + & - & + \\
\hline Bikini & - & + & + & + & + \\
\hline Bonbini & - & + & + & + & + \\
\hline C2-606 & + & - & - & - & - \\
\hline Carmel & - & - & + & - & + \\
\hline Charger & - & - & - & + & - \\
\hline Clipper & + & - & + & - & + \\
\hline Cook & - & - & + & - & + \\
\hline Corfu & - & + & + & + & + \\
\hline Corvette & - & - & + & - & + \\
\hline Crescent & + & - & + & - & + \\
\hline Dolphin & + & - & + & - & + \\
\hline E80. 6282 & - & - & + & - & + \\
\hline Eagle & + & - & + & + & + \\
\hline Ebro & - & + & + & + & + \\
\hline El Forte & - & + & + & + & + \\
\hline El Grinta & - & + & + & + & + \\
\hline El Patriot & - & - & - & $+1-$ & - \\
\hline El Real & - & - & - & $+1-$ & - \\
\hline Emilia & - & + & + & + & + \\
\hline Emu & - & + & + & + & + \\
\hline Fallgreen & + & + & + & + & + \\
\hline Finch & - & - & - & - & + \\
\hline Flamingo & - & - & - & $+1-$ & - \\
\hline
\end{tabular}

\footnotetext{
a A plant showing chlorosis and sporulation on cotyledons, true leaves, or both was classified as susceptible (+), while a plant without chlorosis or sporulation was rated as resistant (-). A spinach line was classified as susceptible if more than $85 \%$ of the plants were diseased (+), whereas a line was classified as resistant if less than $15 \%$ of plants were diseased (-). More than $15 \%$ but less than $85 \%$ of susceptible plant could indicate that a line was segregating for resistance (i.e., +/-).
} 


\section{Results}

New races of the spinach downy mildew pathogen. Isolate UA2708 was collected from the cultivar 'Pelican' in 2008 in San Lucas, CA. When tested on differentials, an intermediate disease reaction (disease incidence $>15 \%$ and $<85 \%$ infection) indicated that this isolate may have been a mixture of more than one race The cultivar Lazio was resistant to the previously described races 1 to 10 (12), so Lazio was inoculated with the inoculum collected from the differentials to "purify" the isolate whereby any race 1-10 isolates of $P$. farinosa f. sp. spinaciae that could have been present would not have been able to increase on the race 1-10 resistant

Table 3. (continued from previous page)

\begin{tabular}{|c|c|c|c|c|c|}
\hline Cultivar/line & Race 10 (INT-1) & Race 11 (UA2708PL) & Race 12 (UA2209) & Race 13 (UA0510C) & Race 14 (UA4410) \\
\hline FP469 & + & - & - & - & - \\
\hline Fp505 & + & - & - & - & _- \\
\hline FS11 & + & - & - & - & - \\
\hline FS41 & + & _- & _- & _- & _- \\
\hline FS83 & + & - & - & - & - \\
\hline FZ506 & + & - & + & - & + \\
\hline Giraffe & + & _- & + & _- & + \\
\hline Gowan \# 1 & - & + & + & + & + \\
\hline Gowan \# 2 & _- & - & + & - & + \\
\hline Gowan \# 3 & - & - & - & - & + \\
\hline Gowan \# 4 & - & + & + & + & + \\
\hline Grandi & - & + & + & + & + \\
\hline Hunter & - & - & + & - & + \\
\hline Ibiza & - & + & + & + & + \\
\hline LDSP 930 & - & - & - & $+1-$ & - \\
\hline LDSP 931 & - & _- & _- & + & _- \\
\hline Marabu & - & + & + & + & + \\
\hline Misano & _- & + & + & + & + \\
\hline Mississippi & - & - & + & - & + \\
\hline Missouri & - & - & + & - & + \\
\hline Monza & + & _- & + & - & + \\
\hline NIL1 & + & - & + & - & + \\
\hline NIL2 & _- & + & + & + & + \\
\hline $\mathrm{O}-\mathrm{A}$ & - & - & - & + & - \\
\hline Ohio & - & + & + & + & + \\
\hline Ottawa & - & + & + & + & + \\
\hline Pelican & - & + & + & + & + \\
\hline Pigeon & _- & - & - & - & + \\
\hline Polar Bear & - & + & + & + & + \\
\hline PV 0698 & - & - & + & - & + \\
\hline PV-0692/Thames & - & - & - & - & - \\
\hline PV-7126 & _- & _- & + & _- & + \\
\hline PV-7131 & - & - & - & $+/-$ & - \\
\hline PV-7132 & - & - & + & - & + \\
\hline PV-7136 & - & $+1-$ & $+1-$ & $+1-$ & - \\
\hline PV-7154 & - & - & + & - & + \\
\hline PV-7155 & _- & _- & + & - & + \\
\hline PV-7156 & - & - & + & - & + \\
\hline PV -7157 & - & _- & + & _- & + \\
\hline PV9208 & - & - & - & + & - \\
\hline PV9209 & - & - & - & + & - \\
\hline Queen & + & - & + & - & + \\
\hline Raccoon & - & - & - & + & - \\
\hline Regal & + & - & + & - & + \\
\hline Silver Whale & + & - & - & - & - \\
\hline SPF321 & - & - & + & - & + \\
\hline SPF323 & + & _- & + & - & + \\
\hline SPF324 & $+/-$ & - & + & - & + \\
\hline SPF325 & $+/-$ & - & + & - & + \\
\hline SPF326 & $+/-$ & - & + & - & + \\
\hline SPF327 & - & - & - & + & - \\
\hline Squirrel & - & - & + & - & + \\
\hline Swan & - & - & + & - & + \\
\hline Tasman & - & $+/-$ & $+1-$ & $+1-$ & $+1-$ \\
\hline Tbird & - & - & + & - & + \\
\hline Thames & - & $+/-$ & $+/-$ & $+1-$ & $+1-$ \\
\hline Tonga & - & - & + & - & + \\
\hline Tortoiseshell & + & - & + & - & + \\
\hline Vigore & - & + & + & + & + \\
\hline VSS91 & - & + & + & + & + \\
\hline VSSC-R1 & + & - & + & - & + \\
\hline VSSC-V1 & - & - & + & - & + \\
\hline Waitiki & - & - & - & + & - \\
\hline Wallis & - & - & + & - & + \\
\hline Whale & + & - & - & + & - \\
\hline Yabi & - & + & + & + & + \\
\hline Zebu & - & - & - & - & + \\
\hline
\end{tabular}


Lazio line. The resulting purified isolate, re-named UA2708PL (UA2708 Purified on Lazio), was then used to inoculate the differentials. This isolate was the first isolate that could overcome the resistance of cultivar Lazio, thus was different from known $P$. farinosa f. sp. spinaciae races 1 to 10 and represented a new race that was subsequently designated race 11 (Table 2). Isolates with a race 11 phenotype were also found in the EU in 2008 (unpublished data).

Isolate UA2209 was collected from the cultivar Mississippi, a race 1-11 resistant cultivar, in 2009 in Salinas, CA. This isolate could infect Lazio, a race 1-10 resistant cultivar, and cultivars Dolphin and Avenger, which were resistant to race 11, so the isolate was unique and designated race 12 (Table 2).

Isolate UA0510C was collected from the cultivar Charger in 2010 in Holtville, CA. This isolate could infect the race 1-10 resistant cultivar Lazio and the race 11 and 12 resistant cultivar Califlay, so the isolate was unique and designated race 13 (Table 2).

Isolate UA4410 was collected during 2010 in Oxnard, CA from the cultivar Pigeon, a cultivar resistant to races 1 through 13. The disease responses of the differentials to this isolate were identical to those for race 12 isolates. However, when testing this isolate on some newer cultivars and advanced breeding lines, this isolate could be distinguished from race 12 by its ability to infect a number of additional cultivars including Pigeon, Cello, and Celesta that are resistant to race 12 , so this isolate was unique and was designated as race 14 (Table 2). The IWGP therefore added Pigeon to the standardized set of differentials in 2011.

Other novel downy mildew pathogen isolates. Five deviating isolates of $P$. farinosa f. sp. spinaciae were identified in the current study and have not been sanctioned as new races (Table 4). The PM2 isolate could not infect the cultivar Lazio, but infected all of the Viroflay and Resistoflay plants, and only some of the plants of the other UA differentials, indicating that the isolate was actually a mixture of two or more races. A unique characteristic of this isolate was that it formed oospores in cotyledons and young true leaf tissue (Fig. 2). The production of oospores coincided with a significant reduction in sporangia production on the assayed plants. This was the first observation of oospore formation in tissue in assays since testing began in 1990. Another deviating isolate, UA0209D, was different from race 11 in that it could not infect Lazio. It was also distinct from race 5 because it could not infect 'Campania'. Deviating isolate UA1210A and an isolate derived from it, UA1210APC (UA1210A Purified on Charger), caused identical disease responses on the differentials as isolates of race 11, but these two isolates could also infect the race 11 resistant cultivars Zebu and Charger. Deviating isolate UA4711 could infect 'Lion'; thus it differed from races 11, 12, 13, and 14; however, it could not infect 'Bolero' and Campania, so it was different from race 10 . The disease responses of the differentials to isolate UA1312 were identical to those of race 11 . However, the race 11 resistant cultivar Pigeon was susceptible to UA1312, thus enabling
UA1312 to be differentiated from race 11. A second isolate, designated UA2612, gave the same reactions on the differentials and Pigeon as isolate UA1312 (Table 4).

Dissecting a field isolate that is a mixture of two races. The following protocol effectively documented that some field samples can represent a mixture of two races. Isolate UA2511A was collected from the cultivar Pigeon in Salinas, CA in 2011. All plants of Viroflay, Resistoflay, Bolero, Campania, Califlay, 'Polka', and Lazio were susceptible to this isolate. About $50 \%$ of the plants of Avenger and Dolphin were susceptible, whereas all of the Lion plants were resistant. Spores collected from these susceptible plants were inoculated onto NIL1 line (containing RPF1) and Califlay (containing $R P F 3$ ) separately and incubated in two different growth chambers. One week later, inoculum collected from NIL1 (isolate designated UA2511AP1) and from Califlay (isolate designated UA2511AP3) were used separately to inoculate differentials. UA2511AP1 could infect cultivars Viroflay, Resistoflay, Bolero, Campania, Avenger, Dolphin, and Lazio, but not Califlay, Polka, Lion, and Pigeon, and was therefore classified as race 12 . UA2511AP3 could infect cultivars Resistoflay, Bolero, Campania, Califlay, Polka, and Lazio, but not Avenger, Dolphin, Lion, and Pigeon, and therefore was classified as race 13. After combining UA2511AP1 and UA25AP3, all cultivars except Lion were susceptible to the mixture. In 2011, there were three other isolates identified as mixtures of different races: UA2611A collected from cultivar Mississippi, UA2711 collected from FY10599, and UA3011 collected from Pigeon (Table 1).

Dynamics of spinach downy mildew pathogen races based on survey samples. A total of 188 isolates were recovered for evalua-

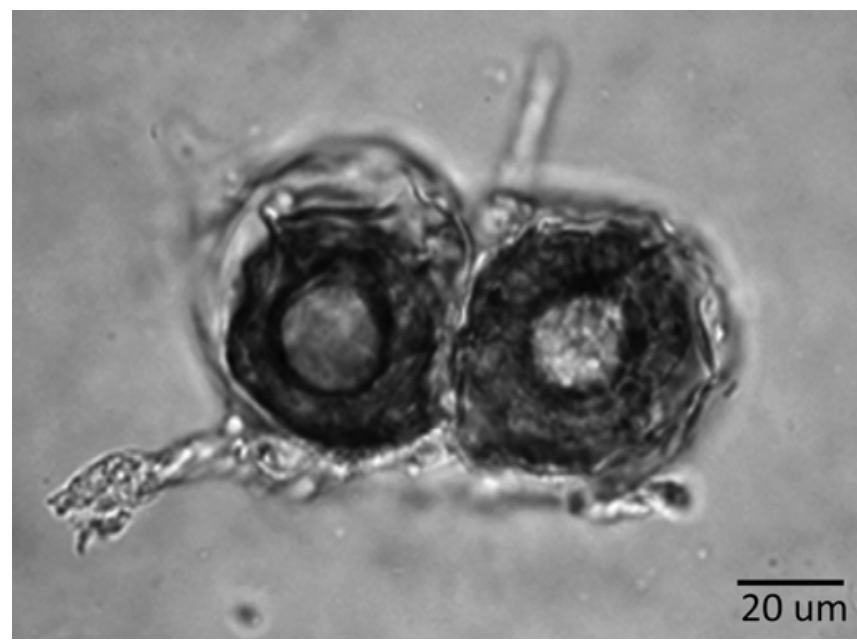

Fig. 2. Oospores generated from an isolate (PM2) of Peronospora farinosa f. sp. spinaciae collected in California in 2007

Table 4. Disease responses of spinach differential cultivars to deviating isolates of Peronospora farinosa f. sp. spinaciae ${ }^{\mathrm{a}}$

\begin{tabular}{|c|c|c|c|c|c|}
\hline Differential & PM2 & UA0209D & UA1210APC & UA4711 & UA1312 \\
\hline Viroflay & + & + & + & + & + \\
\hline Resistoflay & + & + & + & + & + \\
\hline Califlay & $+/-$ & - & - & + & - \\
\hline Polka & $+/-$ & - & - & + & - \\
\hline Bolero & $+/-$ & + & + & - & + \\
\hline Campania & $+/-$ & - & - & - & - \\
\hline Dolphin & $+/-$ & - & - & + & - \\
\hline Avenger & $+/-$ & - & - & + & - \\
\hline Lion & $+/-$ & - & - & + & - \\
\hline Lazio & - & - & + & - & + \\
\hline Pigeon & $\mathrm{nt}$ & nt & - & - & + \\
\hline NIL1 & $\mathrm{nt}$ & nt & - & + & - \\
\hline NIL2 & $\mathrm{nt}$ & nt & + & - & + \\
\hline
\end{tabular}

${ }^{a}$ A plant showing chlorosis and sporulation on cotyledons, true leaves, or both was classified as susceptible (+), while a plant without chlorosis or sporulation was rated as resistant (-). A spinach line was classified as susceptible if more than $85 \%$ of the plants were diseased (+), whereas a line was classified as resistant if less than $15 \%$ of plants were diseased $(-)$. The $+/-$ reactions indicated that PM 2 was a mixture isolate. nt $=$ not tested . 
tion (Fig. 1). A few race 10 isolates of $P$. farinosa f. sp. spinaciae were sampled in 2008 to 2012 but not in 2010 . Race 11 was identified in 2008, and a total of 17 race 11 isolates were recovered in 2008, making it the most common race recovered that year. In the following 4 years, 16, 9, 5, and 1 race 11 isolates were recovered, respectively. Race 12 emerged in 2009 and was the predominant race in 2009 (18 isolates) and 2010 (17 isolates). Race 13 emerged in early 2010 and was present in 2011 and 2012; 11, 30, and 20 race 13 isolates were recovered, respectively. Race 14 was characterized in late 2010 based on a single collected isolate. However, for 2011 and 2012, eight race 14 isolates were recovered each year (Fig. 1). There were four race 5 and one race 6 isolates found in 2008. Four race 4 isolates were sampled during 2008 to 2012, one each in 2008 and 2010, and two in 2012. There is some indication that the race 4 isolates identified in 2012 may be genetically distinct from older European race 4 isolates based on disease reactions of newer germplasm (J. C. Correll and C. Feng, unpublished). However, side-by-side comparisons of older and recently collected race 4 isolates have not been conducted. Two isolates of race 3 were identified, one collected on cultivar Emilia in Texas and one collected on an older cultivar 'Unipack 12' in New Jersey (Table 1).

Putative resistance loci of spinach. Based on the information of parental lines of the differentials and the genetic analysis of resistance, six $P$. farinosa $\mathrm{f}$. sp. spinaciae resistance loci have been hypothesized (4), and the resistance has been demonstrated to segregate as a single dominate resistance gene $(6,11)$. The resistance loci among the differential cultivars are included (Table 2). The universal susceptible cultivar Viroflay does not contain any known resistance to any of the races.

Based on the disease reactions and the resistance loci of the differential cultivars (Table 2), it is apparent that the resistance loci $R P F 1, R P F 3$, and $R P F 6$ were effective against race 11 ; only the $R P F 3$ locus was resistant to races 12 and 14 ; the $R P F 1$ locus was effective against race 13; the resistance loci $R P F 2$ and $R P F 4$ provided resistance against isolate UA4711. However, it is not known if $R P F 6$ can confer resistance for UA4711. The resistance and susceptibility of the six loci to the new races, the novel strains, and previously described races (races 1 to 10) are summarized (Table 5).
The NIL lines were evaluated and the tests have confirmed that the $R P F 1$ locus provides resistance to downy mildew races 1 to 7 , 9,11 , and 13 , but not to races $8,10,12,14$, or UA4711; the NIL2 locus provides resistance to races 1 to 10 and UA4711 but not to races 11 to 14 (Table 6 ).

Susceptibility of cultivars and advanced breeding lines to race 10 and newly designated races $11,12,13$, and 14 . In addition to the two sets of spinach differentials used in the EU and the United States, 103 cultivars and advanced breeding lines also were tested for resistance to races 10 to 14 of $P$. farinosa $\mathrm{f}$. sp. spinaciae (Table 3). Among the 116 cultivars or breeding lines, 79 were resistant and 34 were susceptible to race 10, with three lines apparently segregating at the $R P F 2$ locus (some plants were resistant and others were susceptible in these lines). There were 81 genotypes resistant to and 32 susceptible to race 11 , with three genotypes segregating. Thirty-seven cultivars were resistant to race 12 and 75 were susceptible to this isolate, while four were segregating. There were 60 cultivars resistant to race 13,48 susceptible cultivars, and 8 segregating lines (about 1:1 ratio of resistant:susceptible). There were 30 cultivars resistant to race 14, 84 lines susceptible, and 2 segregating lines. Cultivars and breeding lines 80.8373, 80.8393, 80.9448, Cello, Celesta, Gowan \#3, Finch, Pigeon, and Zebu were resistant to race 12 but susceptible to race 14 , thus differentiating these two races. The other 107 genotypes had identical disease responses to races 12 and 14.

\section{Discussion}

The disease responses of spinach differentials to isolates of $P$. farinosa f. sp. spinaciae indicated that several new races of the pathogen were present. The new races identified in the current study included races $11,12,13$, and 14 . These races were subsequently sanctioned by the International Working Group on Peronospora (IWGP), the governing body that determines if new isolates of $P$. farinosa f. sp. spinaciae should be officially recognized and given a numerical race designation. The IWGP uses criteria such as frequency, geographic distribution, observations in multiple years, and range of susceptible cultivars to determine if a deviating isolate should be sanctioned as a named race.

Table 5. Resistance and susceptibility of six resistance loci to races and deviating strains of Peronospora farinosa f. sp. spinaciae ${ }^{\mathrm{a}}$

\begin{tabular}{|c|c|c|c|c|c|c|c|c|c|c|c|c|c|c|c|c|}
\hline \multirow[b]{2}{*}{ Locus } & \multicolumn{16}{|c|}{ Race } \\
\hline & 1 & 2 & 3 & 4 & 5 & 6 & 7 & 8 & 9 & 10 & 11 & 12 & 13 & 14 & 4711 & 1312 \\
\hline RPF1 & - & - & - & - & - & - & - & + & - & + & - & + & - & + & + & - \\
\hline RPF2 & - & - & - & - & - & - & - & - & - & - & + & + & + & + & - & + \\
\hline RPF3 & - & + & - & + & - & + & + & - & - & + & - & - & + & - & - & - \\
\hline RPF4 & - & - & - & - & + & + & + & + & + & + & + & + & + & + & + & + \\
\hline RPF5 & - & - & + & + & + & + & + & + & + & + & + & + & + & + & - & + \\
\hline RPF6 & - & - & - & - & - & + & - & + & + & + & - & + & + & + & Unknown & - \\
\hline
\end{tabular}

${ }^{a}$ A plant showing chlorosis and sporulation on cotyledons, true leaves, or both was classified as susceptible (+), while a plant without chlorosis or sporulation were rated as resistant (-). A spinach line was classified as susceptible if more than $85 \%$ of the plants were diseased (+), whereas a line was classified as resistant if less than $15 \%$ of plants were diseased (-).

Table 6. Disease responses of a new set of differentials to races and novel isolates of Peronospora farinosa f. sp. spinaciae ${ }^{\mathrm{a}}$

\begin{tabular}{|c|c|c|c|c|c|c|c|}
\hline Cultivar & Race 10 & Race 11 & Race 12 & Race 13 & Race 14 & UA4711 & UA1312 \\
\hline Viroflay & + & + & + & + & + & + & + \\
\hline Resistoflay & + & + & + & $+\mathrm{Un}$ & + & + & + \\
\hline Califlay & + & - & - & + & - & + & - \\
\hline Bolero & + & + & + & + & + & - & + \\
\hline Campania & + & - & + & + & + & - & - \\
\hline Dolphin & + & - & + & - & + & + & - \\
\hline Lion & + & - & - & - & - & + & - \\
\hline Pigeon & - & - & - & - & + & - & + \\
\hline NIL1 & + & - & + & - & + & + & - \\
\hline NIL2 & - & + & + & + & + & - & + \\
\hline
\end{tabular}

${ }^{a}$ A plant showing chlorosis and sporulation on cotyledons, true leaves, or both was classified as susceptible (+), while a plant without chlorosis or sporulation was rated as resistant $(-)$. A spinach line was classified as susceptible if more than $85 \%$ of the plants were diseased (+), whereas a line was classified as resistant if less than $15 \%$ of plants were diseased (-). 
Although it is not known what variables have resulted in the rapid increase of 11 new races (races 4 to 14) since 1990, there are a number of potential contributing factors. In the past two decades, spinach production in California and Arizona has changed dramatically to meet consumer demands for convenient, precleaned, and packaged fresh market products. The density of spinach plantings has increased tremendously. In some instances, over 6 million seed per hectare are planted, little crop rotation is practiced, and spinach is planted throughout the year. These cropping conditions probably provide a conducive microclimate and green bridges that increase the propagation and proliferation of this obligate pathogen. In addition, the increase in organic spinach production, for which effective conventional fungicide seed treatments are not permitted, may also be a contributing factor.

Along with changes in production, the pathogen population has likely been subjected to increased selection pressure. The demand for specific horticultural plant types to meet specifications for the baby leaf and teen leaf spinach markets has resulted in the use of many new hybrid spinach cultivars. As downy mildew resistance is typically the primary objective of most breeding programs (14), there has been a recent increase in spinach hybrids with various combinations of resistance to $P$. farinosa $\mathrm{f}$. sp. spinaciae being grown commercially. These factors, along with newer production conditions, likely increased selection pressure on the pathogen to select for new races.

The mechanism by which new races of spinach downy mildew pathogen originate is not known. New races could originate from mutations in endemic clonal lineages of the pathogen and then be distributed to new areas. In addition, new virulence combinations could result from sexual recombination. Although oospores have periodically been observed in washings from spinach seeds (J. C. Correll and C. Feng, unpublished), it has been rare to see oospores of $P$. farinosa f. sp. spinaciae in field samples that have been collected since 1990. The PM2 sample of downy mildew collected in 2007 was unique. After several inoculations on differential spinach lines, the pathogen clearly appeared to show signs of reduced sporangial production followed by a proliferation of oospores in the inoculated tissue. Although the pathogen is known to be heterothallic (10), this was the first field sample whereby oospores of $P$. farinosa $\mathrm{f}$. sp. spinaciae were documented in plant tissue in California spinach. Thus, the presence of both mating types contributing to sexual recombination may be an important factor in the generation of new races of the pathogen. More extensive sampling and molecular analysis of the pathogen population structure, currently underway, should reveal the genetic variation present in the pathogen population in the United States.

The differential set of cultivars has been essential for the characterization of races of $P$. farinosa $\mathrm{f}$. sp. spinaciae and will continue to be of value in assessing changes in virulence phenotypes. A proposed set of differentials is listed in Table 6. However, the development of a set of NILs that contain the various $P$. farinosa $\mathrm{f}$. sp. spinaciae resistance genes will likely help dissect how specific isolates and/or races interact with single resistance loci and thereby provide an improved breeding option in an effort to manage this important disease by the deployment of effective resistance. It was apparent from this study that the differentials have limitations and will have to be continually modified to account for deviating isolates as they emerge. For example, some isolates, although they appear identical in the disease reactions on the known differentials, can be unequivocally discriminated with additional cultivars. Some of these deviating isolates may only be able to infect a very limited set of germplasm, whereas others may be able to infect many genotypes depending on the prevalence of certain sets of resistance combinations. Clearly, the development of a set of molecular markers for the pathogen as well as a better understanding of the diversity of the pathogen and molecular mechanism of resistance to the $R P F$ loci (4) will provide insights for developing durable resistance to $P$. farinosa f. sp. spinaciae.

Although six resistance loci have been hypothesized (4), RPF1, $R P F 2$, and $R P F 3$ currently appear to be the most robust in helping to manage spinach downy mildew disease. Although it is likely that there are a number of additional loci in various lines, primitive collections, and commercial material, no loci have been identified that impart resistance to all of the known 1 to 14 races.

\section{Acknowledgments}

We thank the California Leafy Greens Research Board, various U.S. and EU spinach seed companies, and numerous California growers and field personnel for providing insight into sources of isolates and background details. We also thank the following for assistance with the study: Angela Iglesias, Rikki Minkler, Spencer Fiser, and Patty Ayala.

\section{Literature Cited}

1. Brandenberger, L. P., Correll, J. C., and Morelock, T. E. 1991. Identification of and cultivar reactions to a new race (race-4) of Peronospora farinosa $\mathrm{f}$. sp. spinaciae on spinach in the United States. Plant Dis. 75:630-634.

2. Brandenberger, L. P., Correll, J. C., and Morelock, T. E. 1991. Nomenclature of the downy mildew fungus on spinach. Mycotaxon 41:157-160.

3. Brandenberger, L. P., Morelock, T. E., and Correll, J. C. 1992. Evaluation of spinach germplasm for resistance to a new race (race-4) of Peronospora farinosa f. sp. spinaciae. Hortscience 27:1118-1119.

4. Correll, J. C., Bluhm, B. H., Feng, C., Lamour, K., du Toit, L. J., and Koike, S. T. 2011. Spinach: Better management of downy mildew and white rust through genomics. Eur. J. Plant Pathol. 129:193-205.

5. Correll, J. C., Feng, C., Irish, B. M., Koike, S. T., Morelock, T. E., Bentley, T. C., and Tomlinson, A. N. 2007. Spinach downy mildew: Overview of races and the development of molecular markers linked to major resistance genes. Pages 135-142 in: Advances in Downy Mildew Research. A. Lebeda and P. T. N. Spencer-Philips, eds. Olomouc, The Czech Republic.

6. Correll, J. C., Feng, C., Kammeijer, K. E., and Koike, S. T. 2012. Downy mildew of spinach-An overview of resistance. (Abstr.) Phytopathology 102:S4.26.

7. Correll, J. C., Koike, S. T., Brandenberger, L. P., Black, M. C., and Morelock, T. E. 1990. A new race (race 4) of downy mildew on spinach. Calif. Agric. 44:14-15.

8. Correll, J. C., Morelock, T. E., Black, M. C., Koike, S. T., Brandenberger, L. P., and Dainello, F. J. 1994. Economically important diseases of spinach. Plant Dis. 78:653-660.

9. Dicoteau, D. R. 2000. Vegetable Crops. Prentice Hall, New Jersey.

10. Inaba, T., Takahashi, K., and Morinaka, T. 1983. Seed transmission of spinach downy mildew. Plant Dis. 67:1139-1141.

11. Irish, B. M., Correll, J. C., Feng, C., Bentley, T., and de los Reyes, B. G. 2008. Characterization of a resistance locus (Pfs-1) to the spinach downy mildew pathogen (Peronospora farinosa f. sp. spinaciae) and development of a molecular marker linked to Pfs-1. Phytopathology 98:894-900.

12. Irish, B. M., Correll, J. C., Koike, S. T., and Morelock, T. E. 2007. Three new races of the spinach downy mildew pathogen identified by a modified set of spinach differentials. Plant Dis. 91:1392-1396.

13. Irish, B. M., Correll, J. C., Koike, S. T., Schafer, J., and Morelock, T. E. 2003. Identification and cultivar reaction to three new races of the spinach downy mildew pathogen from the United States and Europe. Plant Dis. 87:567-572.

14. Morelock, T. E., and Correll, J. C. 2008. Spinach breeding. Pages 183-212 in: Vegetable. I. J. Prohens and F. Nuez, eds. Springer, New York.

15. Ryder, E. J. 1979. Leafy salad vegetables. AVI, New York. 